\title{
Distributed hydrological modelling of total dissolved phosphorus transport in an agricultural landscape, part I: distributed runoff generation
}

\author{
P. Gérard-Marchant ${ }^{1}$, W. D. Hively ${ }^{2}$, and T. S. Steenhuis ${ }^{1}$ \\ ${ }^{1}$ Department of Biological and Environmental Engineering, Cornell University, Ithaca, NY 14853, USA \\ ${ }^{2}$ Department of Natural Resources, Cornell University, Ithaca, NY 14853, USA
}

Received: 30 June 2005 - Published in Hydrol. Earth Syst. Sci. Discuss.: 22 August 2005

Revised: 30 November 2005 - Accepted: 21 February 2006 - Published: 26 April 2006

\begin{abstract}
Successful implementation of best management practices for reducing non-point source (NPS) pollution requires knowledge of the location of saturated areas that produce runoff. A physically-based, fully-distributed, GISintegrated model, the Soil Moisture Distribution and Routing (SMDR) model was developed to simulate the hydrologic behavior of small rural upland watersheds with shallow soils and steep to moderate slopes. The model assumes that gravity is the only driving force of water and that most overland flow occurs as saturation excess. The model uses available soil and climatic data, and requires little calibration.
\end{abstract}

The SMDR model was used to simulate runoff production on a 164-ha farm watershed in Delaware County, New York, in the headwaters of New York City water supply. Apart from land use, distributed input parameters were derived from readily available data. Simulated hydrographs compared reasonably with observed flows at the watershed outlet over a eight year simulation period, and peak timing and intensities were well reproduced. Using off-site weather input data produced occasional missed event peaks. Simulated soil moisture distribution agreed well with observed hydrological features and followed the same spatial trend as observed soil moisture contents sampled on four transects. Model accuracy improved when input variables were calibrated within the range of SSURGO-available parameters. The model will be a useful planning tool for reducing NPS pollution from farms in landscapes similar to the Northeastern US.

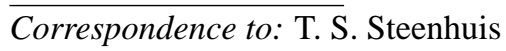

(tss1@cornell.edu)

\section{Introduction}

Reducing agricultural non-point source (NPS) pollution has become a focus for watershed management programs that maintain and improve water quality. Significant NPS pollution originates from hydrologically active areas where runoff is generated, and that also have high soil nutrient concentrations (Gburek et al., 1996). Successful implementation of best management practices for reducing NPS pollution requires the knowledge of the location of frequently-saturated areas prone to overland flow generation, termed hydrologically sensitive areas (HSAs) (Walter et al., 2000).

Overland flow generation can occur by two mechanisms. Infiltration-excess runoff (also called Hortonian overland flow) takes place when precipitation rate exceeds soil infiltration capacity (Horton, 1933, 1940). This mechanism is predominant on low organic matter arid and semiarid soils that are prone to crusting and on compacted areas during highintensity rainfall events. In contrast, saturation-excess overland flow occurs when precipitation falls on saturated soil. Location of saturation-excess overland flow generation does not depend on rainfall intensity but on topography, soil properties, and local hydrological conditions, such as high water table (Hewlett and Hibbert, 1967; Dunne and Black, 1970; Hewlett and Nutter, 1970; Dunne et al., 1975; Beven and Kirby, 1979).

Either infiltration- or saturation-excess processes may predominate at different times and different locations within a watershed. When Hortonian flow dominates, the volume of surface runoff is a function of soil type, land cover and rainfall intensity. Semi distributed models such as SWAT (Arnold et al., 1993, 1994; Di Luzio and Arnold, 2004; Neisch et al., 2002), HSPF (Donigian et al., 1995; Bicknell

Published by Copernicus GmbH on behalf of the European Geosciences Union. 


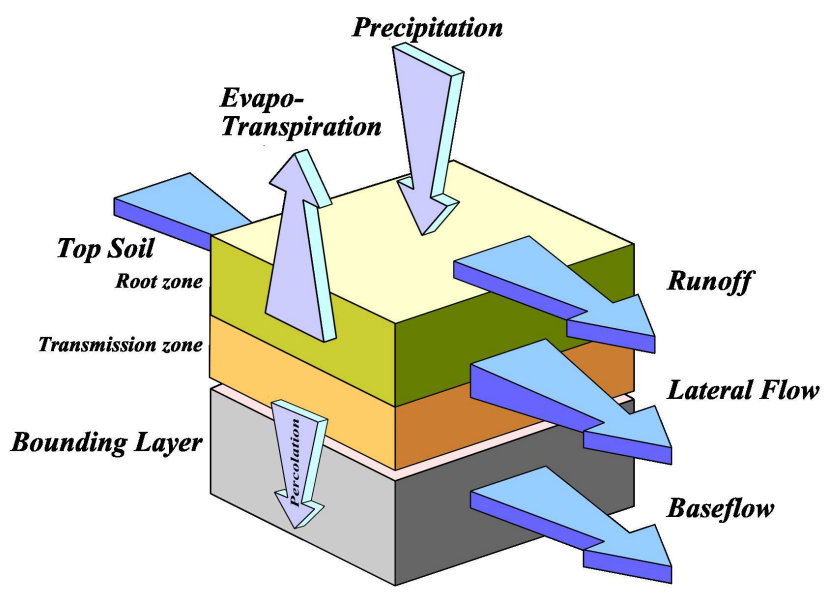

Fig. 1. Schematic representation of the water balance components over one cell.

et al., 1997; Srinivasan et al., 1998) or GWLF (Haith and Shoemaker, 1987; Haith et al., 1992; Schneidermannet al., 2002) are usually based on Hortonian overland flow generation mechanisms. With these models, topographical information is not an important predictor of total runoff and nutrient loads to the streams. However, when overland flow is generated by saturation- excess mechanisms, landscape position is a determining factor, and the temporal distribution of variable source areas must be estimated. Therefore, only models that preserve the spatial information during the simulation can accurately simulate saturation-excess overland flow.

Typical fully-distributed spatial models include the Système Hydrologic Européen, SHE (Abbott et al., 1986a, b; Refsgaard and Storm, 1995); TOPMODEL (Beven, 1997; Beven and Kirkby, 1979; Saulnieret al., 1998); Distributed Hydrology Soil Vegetation Model, DHSVM (Wigmosta et al., 1994; Wigmosta et al., 2002; Wigmosta and Perkins, 2001) and the Soil Moisture Distribution and Routing model, SMDR. The SMDR model is based on a soil moisture balance calculation initially developed by Steenhuis and van der Molen (1986), later modified and integrated into the Geographic Resources Analysis Support System (GRASS) Geographic Information System (GIS) (US Army C.E.R.L., 1991; Neteler and Mitasova, 2002) by Zollweg et al. (1996), Frankenberger et al. (1999) and Kuo et al. (1999). This model is currently maintained by the Soil and Water Laboratory, Cornell University (Soil and Water Laboratory, 2003). SMDR was specifically designed for application on small rural watersheds of the Northeastern United States, characterized by soils overlying slowly permeable layers at shallow depths and moderate to steep slopes. It differs from other models such as SHE or DHVSM in that it uses only readily available input data. Unlike TOPMODEL, it does not assume a water table underlying the whole watershed, but uses soil data on depth to restrictive layer to determine the lower soil boundary.
In the recent years, SMDR has been successfully applied to predict discharge data in several watersheds of the Catskills Mountain region, New York (Frankenberger et al., 1999; Mehta et al., 2004), in Central New York (Kuo et al., 1999; Johnson et al., 2003), and in Pennsylvania (Srinivasanet al., 2005). Validation of the model distributed outputs has been limited due to the difficulty of collecting accurate distributed data.

The objective of this paper is, therefore, to validate SDMR integrated (i.e. runoff at the watershed outlet) and distributed results. The study watershed is a 164-ha dairy farm, located in the northern Catskills region of Delaware County, NY, within the headwaters of Cannonsville reservoir, the third largest reservoir of the New York City water supply system. Streamflows and streamwater nutrient concentrations have been measured at the watershed outlet since 1993 (Bishop et al., 2003, 2005). Detailed management records are also available, and this farm provides an ideal context for application of the model and verification of results.

\section{Description of the SMDR model}

The purpose of SMDR is to identify the location and evolution of variable source areas for overland flow generation and to estimate water fluxes to streams and groundwater. The SMDR is intended as a tool for planners or groups interested in watershed management. Therefore, it does not require extensive calibration and is designed to use data that are readily available in electronic form: (i) a digital elevation map, (ii) a soil type map and the associated table of soil hydrologic properties, (iii) a land use and land cover map, and (iv) weather data (temperature, precipitation and potential evapotranspiration). Details of input data requirements are given in a following section.

Use of SMDR is limited to upland, well-vegetated watersheds, where soils have a high infiltration capacity and slopes over 3\%. In many cases, a low permeability layer, such as bedrock or fragipan, is present at a relatively shallow depth. Watersheds of this type occur not only in the Northeastern United States, but also in many other parts of the world.

The SMDR divides the watershed in square gridcells, with typical cell dimensions ranging from 5 to $30 \mathrm{~m}$. Larger dimensions tend to misrepresent the landscape curvatures and lead to unreasonably high estimates of soil water content (Kuo et al., 1999). In practice, the minimum grid size depends on the resolution of the DEM. Within each cell, soil properties are assumed to be homogeneous. Soil horizons above the low-conductivity restricting layer are grouped into a single surface soil layer. This surface soil layer is then decomposed into two functional sublayers, corresponding to the rooting zone and a transmission zone.

A soil water mass balance is computed for the surface soil of each cell at each time step. A constant daily time step is usually chosen as a good compromise between 
computational speed, accuracy of results, and data availability. Daily water inputs to the top soil layer of each cell are daily precipitation and lateral flow from surrounding upslope cells. Outputs are lateral flow to surrounding downslope cells, percolation through the restrictive layer, and evapotranspiration. A schematic representation of the water balance is illustrated Fig. 1. The water mass balance equation can be expressed for each cell as:

$$
\begin{aligned}
z W^{2}|\theta(t)-\theta(t-\Delta t)| & =|R F(t)+S M(t)| \\
& +Q_{i}(t)-Q_{o}(t) \\
& -E T(t)-P(t)-S E(t)
\end{aligned}
$$

where $z$ is the thickness of the surface soil (m), $W$ the (square) grid size $(\mathrm{m}), \theta$ the cell average water content $\left(\mathrm{cm}^{3} . \mathrm{cm}^{-3}\right), \Delta t$ the time step $(d), R F$ and $S M$ the rainfall and snowmelt volumes, respectively, $Q_{i}$ the volume of water received through lateral flow from surrounding upslope cells, $Q_{o}$ the volume of water lost through lateral flow to surrounding downslope cells, $E T$ the volume of water lost by evapotranspiration, $P$ the volume of water lost by percolation through the bounding layer, and $S E$ the saturation excess runoff. Volumes are expressed in $\left(\mathrm{m}^{3}\right)$. Although the mass balance components are tightly coupled, they are estimated separately for computational simplicity. They are presented hereafter in the order in which they are calculated for each time step.

\subsection{Precipitation}

Daily precipitation is first partitioned into rain or snow, depending on the observed daily mean air temperature $\left({ }^{\circ} \mathrm{C}\right)$, corrected as necessary for local elevation by the adiabatic lapse rate of $6.5 \times 10^{-3}$ C.m ${ }^{-1}$ (Boll et al., 1998). Rainfall $R F$ is identified with precipitation on cells where air temperature is greater than $-1^{\circ} \mathrm{C}$. Snowmelt $S M$ is computed following a simple land-cover dependent temperature index method (US Army Corps of Engineers, 1960). Rainfall and snowmelt occurring on impervious areas, e.g. roads and buildings, are converted directly to overland flow.

\subsection{Moisture redistribution}

Water inputs are assumed to infiltrate and are added to the water already stored in the surface layer. After infiltration, three characteristic moisture $\theta_{f}, \theta_{m}$ and $\theta_{s}$ are considered, corresponding to field capacity, macroporous drainage limit and saturation, respectively. Field capacity is defined as the moisture content below which no drainage takes place. The macroporous drainage limit corresponds to the minimum water content required to activate macropore flows, and is related to the depth to the slowly permeable layer: the shallower the slowly permeable layer, the larger the drainage limit (Boll et al., 1998). The moisture content at saturation is identified with effective porosity (i.e. porosity corrected by rock fragment and organic matter content).
When the average soil water content $\bar{\theta}$ is less than the macroporous drainage limit, the moisture profile is assumed uniform throughout the top layer of soil. Otherwise, a saturated layer of thickness $z_{s}$ is formed, with average water content $\bar{\theta}$, so that

$z \bar{\theta}=\left(z-z_{s}\right) \theta_{m}+z_{s} \theta_{s}$

\subsection{Lateral flows}

Lateral outflows are calculated by integrating Darcy's law over soil depth, grid width and time step. After identifying the hydraulic gradient with the local surface slope $\sigma$ $\left(\mathrm{m} . \mathrm{m}^{-1}\right)$, and assuming that the hydraulic conductivity does not vary significantly with position or time during one time step, it comes eventually:

$Q_{o}=-\kappa K(\theta) z W \sigma \Delta t$

where $K$ is the average hydraulic conductivity of the layer $\left(m_{\text {.day }}{ }^{-1}\right), \kappa$ a depth-dependent multiplier (typical range of 2 to 10) introduced to correct transmissivities for preferential flows in macropores (Boll et al., 1998). The average hydraulic conductivity $K$ is defined as:

$$
\begin{array}{ll}
K(\theta)=0 & \text { for } \theta<\theta_{f} \\
K(\theta)=K_{s} \exp \left[-\alpha \frac{\theta_{s}-\theta}{\theta_{s}-\theta_{f}}\right] & \text { for } \theta_{f} \leq \theta<\theta_{m} \\
K(\theta)=K_{m}+K_{s} \frac{\theta-\theta_{m}}{\theta_{s}-\theta_{m}} \quad \text { for } \theta_{m} \leq \theta
\end{array}
$$

where $K_{s}=K\left(\theta_{s}\right)$ and $K_{m}=K\left(\theta_{m}\right)$ are the hydraulic conductivity at saturation and at macroporous drainage limit, respectively, and $\alpha$ is an universal constant equal to 13 for a large range of soils (Bresler et al., 1978; Steenhuis and van der Molen, 1986).

Lateral outflows from each cell are then distributed according to local aspect between one cardinal and one diagonal downslope neighboring cells, following the $D_{\infty}$ algorithm (Tarboton, 1997). On each cell, the lateral inflow $Q_{i}$ is defined as the sum of the contributions received from the upslope surrounding cells.

\subsection{Evapotranspiration}

Evapotranspiration $E T$ is calculated by solving the differential equation:

$z_{r} \frac{d \theta}{d t}=-K_{c} E$

where $z_{r}$ is the depth of the rooting zone $(\mathrm{m}), K_{c}$ a basal evapotranspiration coefficient introduced to reflect differences among vegetation types (-) (Allen et al., 1998), and $E$ the evapotranspiration rate $\left(\mathrm{m}^{-} \mathrm{day}^{-1}\right)$. Following Thornthwaite and Mather (1955), it is assumed that $E$ varies linearly with water content, from 0 at permanent wilting point, $\theta_{p}\left(\mathrm{~cm}^{3} . \mathrm{cm}^{-3}\right)$, to the potential evapotranspiration 
rate, $E_{\text {ref, }}$ when soil moisture exceeds a given "evapotranspiration limit" $\theta_{l}$, usually set to field capacity. The potential evapotranspiration rate $E_{r e f}$ is calculated daily from temperature data, following the Hargreaves and Samani's (1985) method or a simplified Priestley and Taylor (1972) method. Rooting depths $z_{r}$ and basal coefficients $K_{c}$ are calculated for each vegetative cover, depending on its development stage. Vegetative development is calculated as a function of cumulative growing degree-days, i.e. the cumulative difference of daily average temperatures and a vegetationtype dependent basal temperature $T_{b}\left({ }^{\circ} \mathrm{C}\right)$. Five development stages are defined, according to cumulative growing degreeday thresholds and a final winter cutoff condition (Jensen et al., 1990). Growing degree-days accumulation starts when average daily air temperature is larger than the basal temperature $T_{b}$ for five consecutive days (Goudriaan and van Laar, 1994). Data for the basal coefficients and growing-degree day threshold are compiled from literature or estimated from local records.

\subsection{Percolation}

Percolation of water through the fractures and cracks in the bedrock and, to a lesser extent, through the dense fragipan (Soren, 1963), is computed for each cell as:

$P=\min \left[K(\theta) ; K_{\mathrm{sub}}\right] W^{2} \Delta t$

where $K_{\text {sub }}$ is the conductivity at saturation of the cell substratum, $\left(\mathrm{m} \cdot \mathrm{day}^{-1}\right)$, and where the hydraulic conductivity $K$ is given by Eq. (4). Percolation stops when the average water content of the bottom structural layer is less than field capacity.

Identification of percolation pathways requires some knowledge of the geometry of the fractures. Unfortunately, such data are scarce. Therefore, it is assumed that at each time step, only a fraction $r$ of the total percolating volume flows to the streams, with the remainder lost to regional flow. Percolation to the stream constitutes the stream baseflow $B F$ $\left(\mathrm{m}^{3}\right)$, such as

$$
B F=r \sum_{i} P_{i}
$$

where $P_{i}$ is the percolation volume simulated on cell $(i)\left(\mathrm{m}^{3}\right)$, and where the summation domain is the entire watershed. Conceptually, this does not mean that a drop of water that percolates in the substratum becomes immediately baseflow. Water, as in previous versions of the model, enters into a subsurface reservoir. In the current implementation, the reservoir volume is fixed so that for each quantity of water that enters the reservoir, a similar quantity becomes baseflow. Although for the water balance the distinction of what water enters the stream as baseflow is immaterial, it becomes important when nutrient transport is considered.

\subsection{Overland flow and streamflow generation}

At the end of each time step, any water in excess of saturation becomes saturation excess overland flow $S E\left(\mathrm{~m}^{3}\right)$. Overland flow is routed directly to the watershed outlet. Re-infiltration and interaction of overland flow with downslope soils are not considered.

\section{Input data}

Refsgaard and Strom (1996) stress that for a rigorous parametrization of hydrological systems, only the parameters that are pertinent to modeling and that can be directly measured or derived from field data should be selected. In SMDR, computation of the water balance requires, in addition to climatic input, the knowledge of several parameters on each cell: $z, \theta_{p}, \theta_{l}, \theta_{f}, \theta_{m}, \theta_{s}, \kappa, K_{s}, z_{r}, K_{c}$, and $K_{\text {sub }}$. Another parameter, the percolation coefficient $r$, has to be estimated on the watershed scale. To limit the risk of overparameterisation (Beven, 1996), parameters are actually grouped in generic classes reflecting only significant spatial variations. Typical classes consist of soil units, soil horizons, vegetative types and land covers. Parameter classes for the study watershed are defined in a following section.

\subsection{Weather information}

Daily minimum and maximum temperatures were obtained from a nearby weather station located at Delhi, New York, 438.9 m.s.l., (National Weather Service (USDC NOAA) cooperative observer station \#302036, "Delhi 2 SE"), located about $20 \mathrm{~km} \mathrm{SW}$ of the site (NCDC, 2000). Temperatures were corrected by $-1.2^{\circ} \mathrm{C}$ to account for the difference of elevation with the study watershed. Potential evapotranspiration rates $E_{r e f}$ were calculated from daily temperature data, following the Priestley and Taylor (1972) method. Precipitation was recorded at a 10-min interval, and integrated over one day. Onsite precipitation records were available from 1998 to 1999 only, for air temperatures greater than $1^{\circ} \mathrm{C}$. When onsite information was not available, daily precipitation records from the Delhi weather station were used instead. Daily stream flows were recorded on a 10-min basis by a gauge at the watershed outlet, and integrated over one day (Bishop et al., 2003).

\subsection{Parameter classes}

\subsubsection{Topographic map}

Elevation data were obtained from the USGS as a 1:24000, $10-\mathrm{m} \times 10-\mathrm{m}$ horizontal, $0.1-\mathrm{m}$ vertical resolution digital elevation map (USGS, 1998). The watershed boundary was first derived using the Arcview Basins extension (ESRI, 2002), then was modified to reflect the effect of a farm access road 


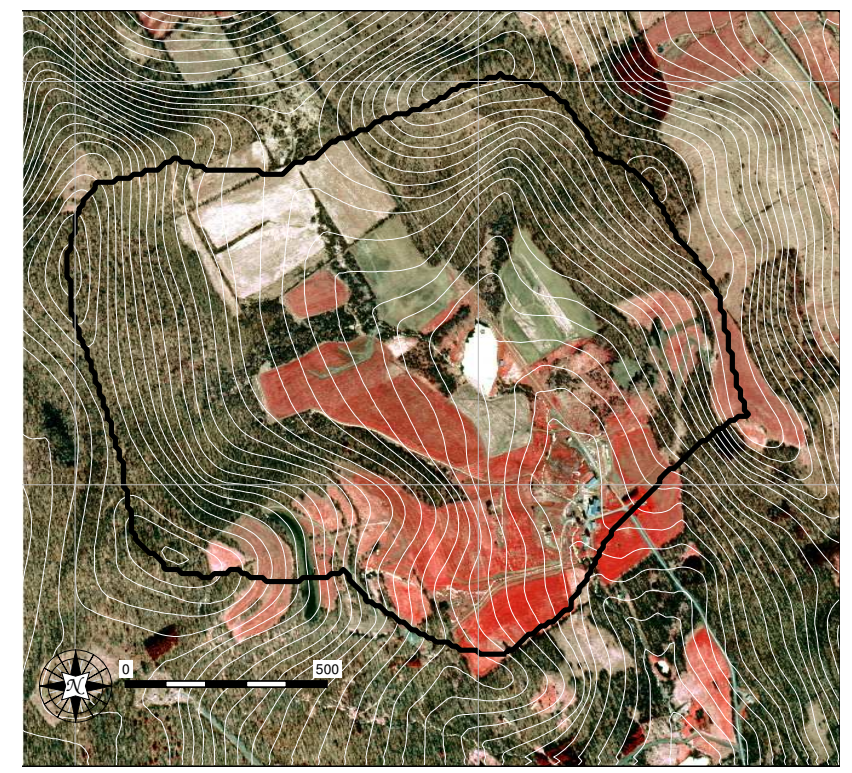

Fig. 2. Aerial photograph of the study watershed, with 5-m elevation contours (white lines). Solid black line: watershed boundary.

and to match the area above the streamflow monitoring station, and was finally verified by Hively (2004). An aerial photograph of the watershed, with 5-m elevation contours, is presented Fig. 2. Study watershed elevations range from 600 to $740 \mathrm{~m}$.s.l. The main flow direction is oriented NNW-SSE. Slopes on the upper part of the watershed range from 2 to $40 \%$ (with an average about $17 \%$ ), while slopes on the lower part range from 0 to $20 \%$ (with an average about $8 \%$ ).

\subsubsection{Soil type classes}

Soil types and characteristics were derived from the SSURGO database (USDA-NRCS, 2000). The steeper, shallower (average thickness $65 \mathrm{~cm}$ ) upper terrains are characterized by Halcott channery loams (loamy-skeletal, mixed, active, frigid Lithic Dystrudepts) and Vly channery silty loams (loamy-skeletal, mixed, superactive, frigid Typic Dystrudepts). These terrains overlay a fractured horizontal bedrock. The flatter, deeper (average thickness $180 \mathrm{~cm}$ ) lower terrains consist of moderately-well-drained Willowemoc channery silt loams (coarse, loamy, mixed, frigid, Typic Fragiochrepts) and Onteora silt loams (coarse-loamy, mixed, semiactive, frigid Aquic Fragiudepts). These terrains are restricted by a dense fragipan. The watershed soil map is presented in Fig. 3. No independent validation was carried out on the exact location of the boundaries between soil types.

\subsubsection{Land covers and land uses}

Because readily available MRLC land cover data were not sufficiently detailed for modeling at a $10-\mathrm{m}$ gridcell resolution, a 1-m Chromatic InfraRed (CIR) digital orthophoto-

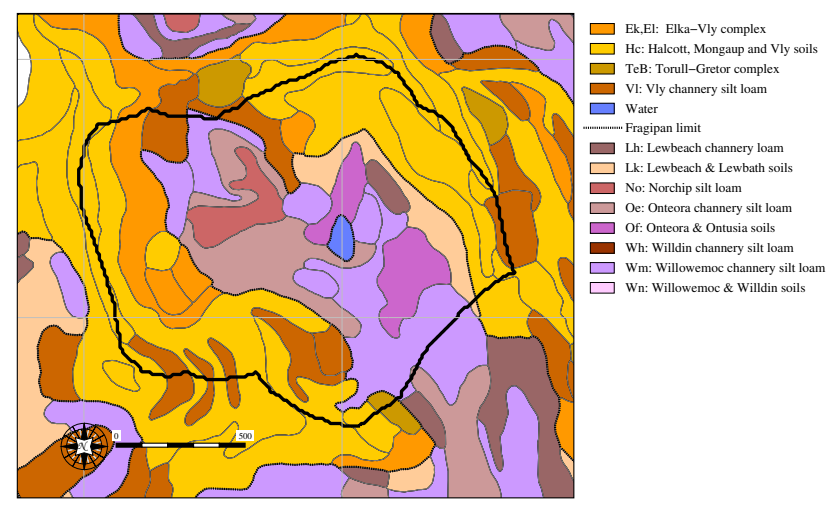

Fig. 3. SSURGO soil units map for the study watershed. Solid black line: watershed boundary; dotted black line: fragipan-bedrock boundary

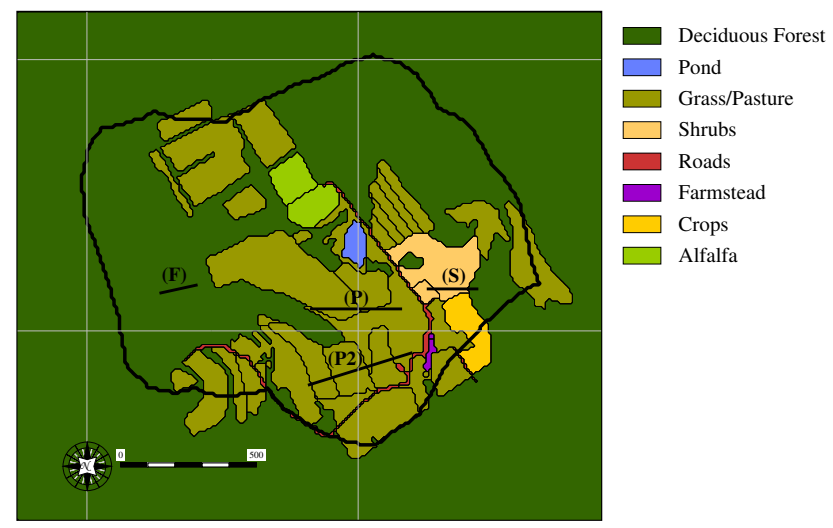

Fig. 4. Field boundaries, land uses for 2001 and sampling transects location.

graph quadrangle quarter (DOQQ) covering the study watershed (taken on 1-6 December 2000; NYSDoS, 2000), was used as a basemap for high-resolution on-screen digitization of field boundaries, impermeable areas, and other important landscape features. Combination of this information with field observations, GPS data, farm planning records, and farmer interview provided sufficient detail to produce $10-\mathrm{m}$ land use raster maps reflecting annual changes in crop rotation (Hively, 2004). Land use categories were based upon the National Land Cover Data (NLCD) classification system (NLCD, 1997), with the addition of several categories specific to local farm management practices. The map of field boundaries and corresponding land uses for 2001 is presented in Fig. 4. About 53\% of the watershed area is covered by deciduous forest. The lower slopes consist of improved pasture and hay $(27 \%)$, unimproved pasture $(11 \%)$, rotated maize $(7 \%)$ and impermeable areas such as roadways and barnyards (2\%). 
Table 1. Vegetation and land uses properties used in the calculation of evapotranspiration: rooting depth $z_{r}$, basal evaportranspiration coefficient $K_{c}$, base temperature $T_{b}$ and growing degree thresholds $D D$.

\begin{tabular}{lccccccccc}
\hline & \multicolumn{2}{c}{$\begin{array}{c}z_{r}(\mathrm{~mm}) \\
\min \end{array}$} & \multicolumn{2}{c}{$K_{c}$} & $T_{b}$ & $D D_{\max }$ & $\begin{array}{c}D D_{12} \\
(\%)\end{array}$ & $\begin{array}{c}D D_{23} \\
(\%)\end{array}$ & $\begin{array}{c}D D_{34} \\
(\%)\end{array}$ \\
\hline Open Water & 0 & 0 & 1.00 & 1.00 & 0 & 0 & 0 & 0 & 0 \\
Roads/Buildings & 0 & 0 & 1.00 & 1.00 & 0 & 0 & 0 & 0 & 0 \\
Deciduous Forest & 1500 & 1500 & 0.25 & 1.00 & 1 & 3500 & 0.10 & 0.15 & 0.93 \\
Shrubland & 750 & 750 & 0.20 & 1.00 & 1 & 2700 & 0.08 & 0.13 & 0.95 \\
Grasslands/Herbaceous & 600 & 600 & 0.20 & 1.00 & 1 & 4000 & 0.05 & 0.10 & 0.97 \\
Row Crops & 75 & 750 & 0.40 & 1.10 & 5 & 2100 & 0.15 & 0.40 & 0.90 \\
Small Grains & 75 & 750 & 0.40 & 1.10 & 5 & 2000 & 0.15 & 0.40 & 0.90 \\
Fallow & 600 & 600 & 0.20 & 1.00 & 3 & 3500 & 0.05 & 0.10 & 0.97 \\
Alfalfa & 1500 & 1500 & 0.20 & 1.20 & 1 & 4000 & 0.05 & 0.10 & 0.97 \\
Grass/Hay + grazing & 600 & 600 & 0.20 & 1.00 & 1 & 4000 & 0.05 & 0.10 & 0.97 \\
\hline
\end{tabular}

Table 2. Soil characteristics for the study watershed.

\begin{tabular}{|c|c|c|c|c|c|c|c|c|c|c|c|}
\hline & Soil & $\begin{array}{c}z \\
(\mathrm{~mm})\end{array}$ & $\begin{array}{c}\text { Rock }^{1} \\
(\%)\end{array}$ & $\begin{array}{c}\mathrm{OM}^{2} \\
(\%)\end{array}$ & $\begin{array}{l}\theta_{w} \\
(\%)\end{array}$ & $\begin{array}{c}\theta_{f} \\
(\%)\end{array}$ & $\begin{array}{l}\theta_{m} \\
(\%)\end{array}$ & $\begin{array}{c}\theta_{s} \\
(\%)\end{array}$ & $\begin{array}{c}K_{\text {sat }} \\
\left(\mathrm{mm} \cdot \mathrm{d}^{-1}\right)\end{array}$ & $\kappa$ & $\begin{array}{c}\text { Boun- } \\
\text { ding } \\
\text { Layer }^{3}\end{array}$ \\
\hline Ek & Elka-Vly complex & 1500 & 15.0 & 0.0 & 7.5 & 22.5 & 27.5 & 47.5 & 800 & 4 & $\mathrm{D}$ \\
\hline El & Elka-Vly complex & 1800 & 17.5 & 0.5 & 7.5 & 22.5 & 25.0 & 47.5 & 800 & 2 & $\mathrm{D}$ \\
\hline $\mathrm{Hc}$ & Halcott, Mongaup and Vly soils & 500 & 52.5 & 0.5 & 10.0 & 20.0 & 32.5 & 45.0 & 800 & 6 & $\mathrm{D}$ \\
\hline $\mathrm{Lh}$ & Lewbeach channery loam & 500 & 25.0 & 2.5 & 10.0 & 20.0 & 32.5 & 50.0 & 700 & 7 & $\mathrm{R}$ \\
\hline $\mathrm{Lk}$ & Lewbeach and Lewbath soils & 500 & 27.5 & 2.5 & 10.0 & 22.5 & 35.0 & 50.0 & 1000 & 7 & $\mathrm{R}$ \\
\hline No & Norchip silt loam & 300 & 7.5 & 6.5 & 12.5 & 30.0 & 50.0 & 52.5 & 1000 & 7 & $\mathrm{R}$ \\
\hline Oe & Onteora channery silt loam & 300 & 22.5 & 4.0 & 10.0 & 22.5 & 40.0 & 52.5 & 1000 & 7 & $\mathrm{R}$ \\
\hline Of & Onteora and Ontusia soils & 300 & 27.5 & 3.5 & 10.0 & 22.5 & 40.0 & 52.5 & 1000 & 7 & $\mathrm{R}$ \\
\hline $\mathrm{Te}$ & Torull-Gretor complex & 500 & 17.5 & 2.5 & 12.5 & 25.0 & 40.0 & 47.5 & 200 & 7 & $\mathrm{D}$ \\
\hline Vl & Vly channery silt loam & 800 & 47.5 & 2.0 & 12.5 & 22.5 & 32.5 & 47.5 & 800 & 6 & $\mathrm{D}$ \\
\hline $\mathrm{Wm}$ & Willowemoc channery silt loam & 500 & 22.5 & 1.5 & 10.0 & 22.5 & 35.0 & 52.5 & 800 & 4 & $\mathrm{R}$ \\
\hline
\end{tabular}

1 Rock and gravel content.

2 Organic matter content.

${ }^{3}$ Bounding layer type - R: restricting (fragipan) - D : draining (bedrock).

\subsection{Parameters definition}

\subsubsection{Vegetation properties}

Minimum and maximum values of the basal evapotranspiration coefficient $K_{c}$ and the rooting depth $z_{r}$ were derived from generic values reported in the literature (Jensen et al., 1990; Allenet al., 1998). For each vegetation type, growing degree-days thresholds and basal temperatures were adjusted prior to simulation, to reflect times of budding, leaf emergence and full canopy representative of the Central New York climate. Relevant information is reported in Table 1.

\subsubsection{Directly available soil properties parameters}

Look-up tables associated with the SSURGO database provided the basis for the definition of soil properties for each soil type. Only the data pertaining to the main soil sequence for each soil type were taken into account. For each structural layer of each soil type, the SSURGO database reports expected ranges of porosity, rock content, organic matter, available volumetric water contents and hydraulic conductivity at saturation. Only the midrange values were considered for the uncalibrated runs. Porosity and available water content were furthermore corrected for rock and organic matter content. Saturated hydraulic conductivity were determined on disturbed samples and therefore indicate only the conductivity of the soil matrix without macropores. The 

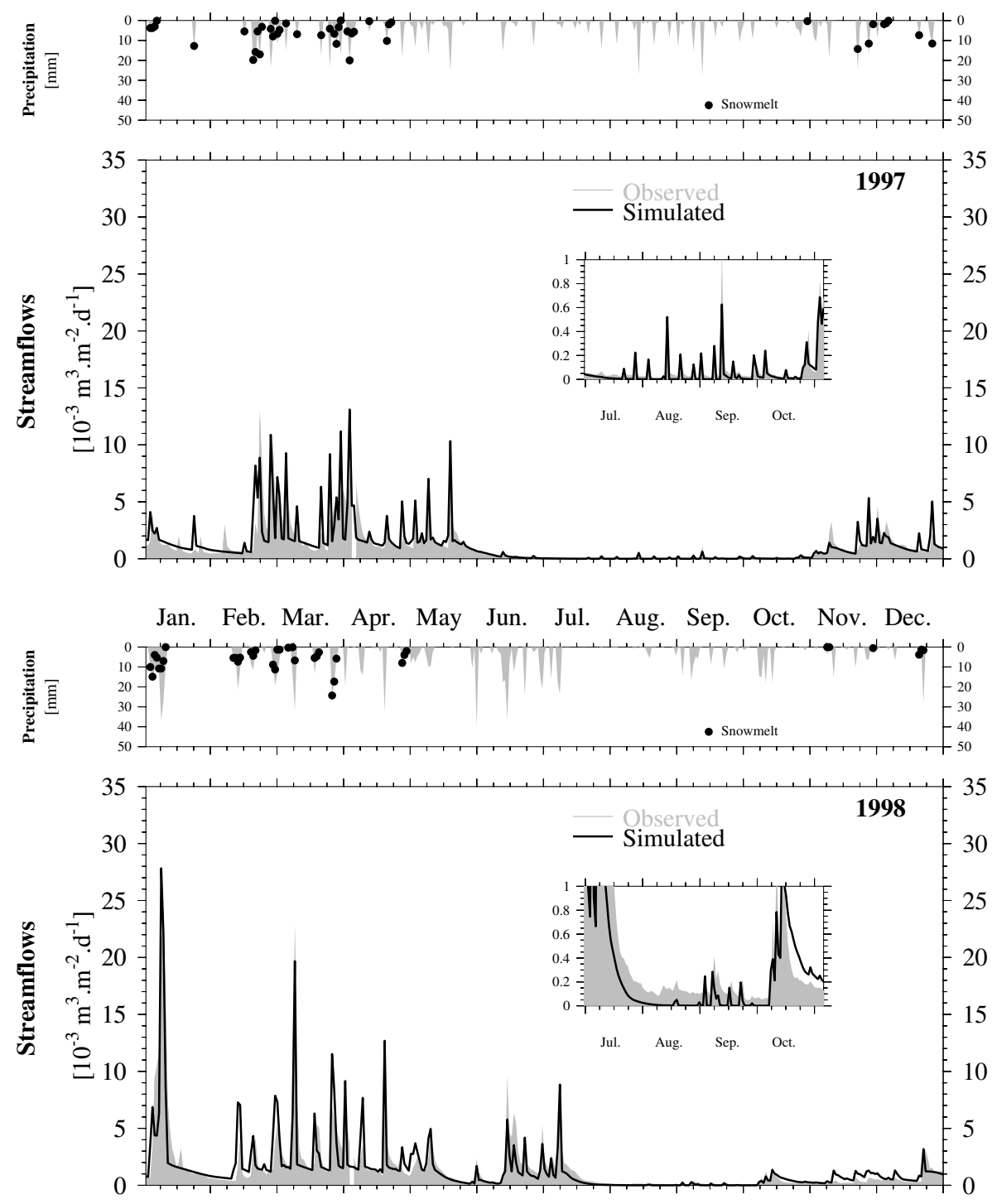

Jan. Feb. Mar. Apr. May Jun. Jul. Aug. Sep. Oct. Nov. Dec.

Fig. 5. (a)-(d) Comparison between observed (filled grey curve) and simulated (soild black line) hydrographs.

effect of macropores is based on the procedures by Boll et al. (1988) as described in Eq. (4). The selected properties values were then weighted by the structural layer thickness, averaged over the composite topsoil layer and rounded. Parameters values for each soil type are presented in Table 2 .

In previous versions of the model, the main soil sequence was decomposed as the superposition of several structural layers, as described by the SSURGO data base (Johnson et al., 2003; Metha et al., 2004). In the current version, the structural layers above the restricting layer (bedrock or fragipan) are aggregated into a composite surface soil layer, and soil depth $z$ is defined as the sum depth of this composite layer.
Wilting point $\theta_{p}$ was calculated as the water content at $-1500 \mathrm{kPa}$, using SSURGO values of organic matter and clay contents, and a linear regression equation developed by Rawls and Brakensiek (1985). Field capacity $\theta_{f}$ was calculated as the sum of $\theta_{p}$ and the midrange of SSURGO values for available water content. Evapotranspiration limit $\theta_{l}$ was set to field capacity.

\subsubsection{Estimated soil properties parameters}

Only four parameters are not readily available and have to be estimated: macroporous drainage limit $\theta_{m}$, horizontal hydraulic conductivity multipliers $\kappa$, hydraulic conductivity at 

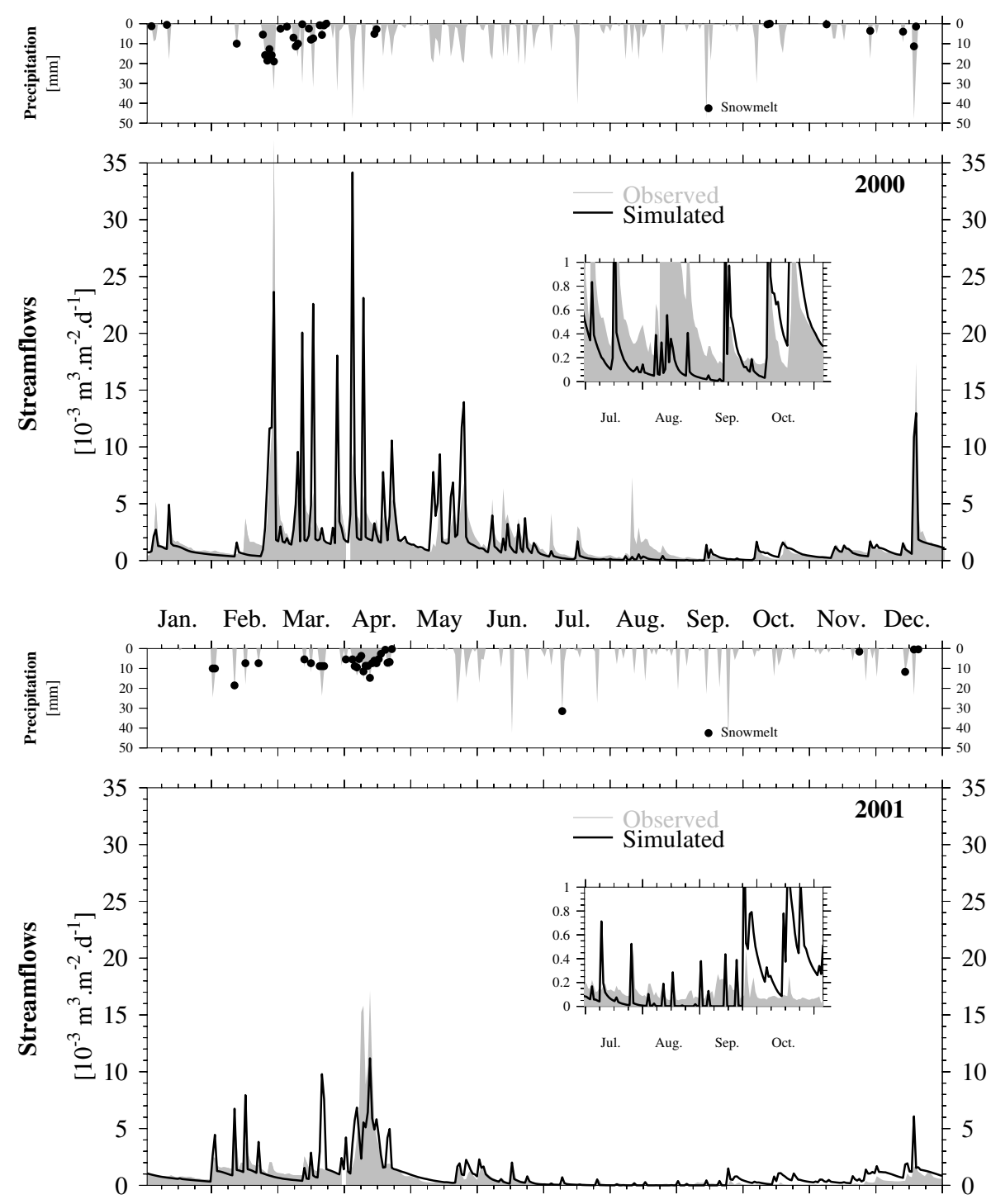

Jan. Feb. Mar. Apr. May Jun. Jul. Aug. Sep. Oct. Nov. Dec.

Fig. 5. Continued.

saturation of the bounding layer $K_{\text {sub }}$, and percolation fraction delivered to streamflow, $r$.

In previous versions of the model, decreasing values of the multipliers $\kappa$ were allocated from the top structural layer to the bottom one (Mehta et al., 2004). In the current version, the multipliers were assumed to decrease exponentially with topsoil thickness, from 10 for the shallowest soils of the watershed to 2 for the deepest ones. The values were initially chosen to reproduce field observations that hydraulic conductivities derived from bore hole measurements were up to one order of magnitude larger than those reported in the SSURGO database, for which conductivities are determined on disturbed samples (unpublished data).
The macroporous drainage limit, $\theta_{m}$, is a key parameter controlling subsurface lateral flows and percolation. Preliminary investigations indicated that if $\theta_{m}$ was set to a low value, simulated percolation would last for too long a period for wet soils, as compared with observed baseflows, and would restart after a too short period for dry soils, leading to overestimated baseflows at the beginning and end of the summer period. Eventually, for soils with a restrictive layer of less than $3 \mathrm{~m}$, the parameter was estimated from field capacity and soil depth, through the relation:

$\theta_{m}=\theta_{f}|3 / z|^{1 / 4}$

with the soil depth $z$ expressed in $(m)$. This relation relies on the hypotheses that under hydrostatic conditions, the soil 
Table 3. Comparison of annual, summer and winter values of observed and simulated daily streamflows and efficiency criteria for the simulated period (1 January 1994-31 December 2001).

\begin{tabular}{llllllllll}
\hline Year & All & 1994 & 1995 & 1996 & 1997 & 1998 & 1999 & 2000 & 2001 \\
\hline Annual & & & & & & & & & \\
Precipitation (mm) & 8577 & 1184 & 1047 & 1472 & 866 & 993 & 951 & 1230 & 834 \\
Obs. Flows (mm) & 4531 & 702 & 494 & 883 & 424 & 552 & 473 & 675 & 328 \\
Simul. flows (mm) & 4412 & 632 & 492 & 898 & 424 & 520 & 464 & 638 & 344 \\
MNS $^{\mathrm{a}}$ & 0.661 & 0.632 & 0.638 & 0.604 & 0.769 & 0.746 & 0.635 & 0.413 & 0.579 \\
MAE $^{\mathrm{b}}$ & 0.436 & 0.448 & 0.385 & 0.383 & 0.515 & 0.516 & 0.418 & 0.287 & 0.388 \\
$\mathrm{R}^{2}$ & 0.584 & 0.571 & 0.465 & 0.625 & 0.581 & 0.752 & 0.673 & 0.483 & 0.496 \\
\hline Summer (1 May-31 October) & & & & & & & & \\
Precipitation (mm) & 4422 & 611 & 588 & 776 & 367 & 515 & 480 & 604 & 480 \\
Obs. Flows (mm) & 1155 & 155 & 87 & 310 & 73 & 163 & 88 & 229 & 51 \\
Sim. flows (mm) & 1157 & 161 & 141 & 303 & 76 & 121 & 106 & 183 & 66 \\
MNS & 0.656 & 0.568 & 0.505 & 0.757 & 0.903 & 0.733 & 0.336 & 0.182 & -0.301 \\
MAE & 0.473 & 0.390 & 0.271 & 0.513 & 0.760 & 0.573 & 0.354 & 0.212 & 0.065 \\
$\mathrm{R}^{2}$ & 0.633 & 0.489 & 0.700 & 0.732 & 0.896 & 0.779 & 0.717 & 0.443 & 0.538 \\
\hline Winter (1 January-31 March, 1 November-31 December) & & & & & \\
Precipitation (mm) & 4155 & 573 & 459 & 696 & 499 & 478 & 471 & 625 & 354 \\
Obs. Flows (mm) & 3376 & 548 & 407 & 573 & 351 & 389 & 385 & 446 & 277 \\
Sim. flows (mm) & 3255 & 472 & 350 & 595 & 348 & 399 & 358 & 455 & 278 \\
MNS & 0.506 & 0.526 & 0.257 & 0.457 & 0.439 & 0.707 & 0.407 & 0.444 & 0.531 \\
MAE & 0.335 & 0.385 & 0.194 & 0.275 & 0.298 & 0.469 & 0.294 & 0.298 & 0.287 \\
$\mathrm{R}^{2}$ & 0.539 & 0.535 & 0.357 & 0.586 & 0.427 & 0.737 & 0.664 & 0.465 & 0.440 \\
\hline
\end{tabular}

${ }^{a}$ Modified Nash Sutcliffe criterion (Chiew and McMahon, 1994). ${ }^{\text {b }}$ Mean Absolute Error (Ye et al., 1997).

water pressure - water content relationship is described by the Brooks and Corey (1964) model, and that field capacity is identified with the water content at a pressure of $-30 \mathrm{kPa}$ (equivalent to $3 \mathrm{~m}$ of water column). The exponent in Eq. (8) corresponds to a generic value of Brooks-Corey pore size distribution index over a wide range of soils.

Following Frankenberger et al. (1999), a generic value of $1 \mathrm{~mm} \cdot$ day $^{-1}$ was assumed for the saturated conductivity of fragipan layers, while a saturated conductivity of $2 \mathrm{~mm} \cdot$ day $^{-1}$ was assumed for the slowly permeable bedrock layers. The percolation fraction $r$, was calibrated after simulation to a value of 0.677 , in order to match observed flows during a dry summer period (1997).

\section{SMDR model integrated results}

The SMDR model was applied to the study watershed over a 9-year period (1 January 1993 to 31 December 2001). The resulting hydrographs are presented in Figs. 5a-h. The first year of simulation (1993) is not shown as it was affected by the assumed initial water storage conditions. Outputs for each year were decomposed into two 6-month seasons, "summer" (May-October) and "winter" (November-April).

From 1993 to 2001, a total of $8577 \mathrm{~mm}$ of precipitation was recorded (4422 and $4155 \mathrm{~mm}$ for summer and winter periods, respectively), and $4531 \mathrm{~mm}$ of streamflow was observed (1155 and $3376 \mathrm{~mm}$ for summer and winter periods, respectively). For the same period, simulated streamflow was $4412 \mathrm{~mm}$ (1157 and $3255 \mathrm{~mm}$ for summer and winter periods, respectively). Precipitation and observed and simulated streamflows are reported for each simulated year in Table 3, along with the values of three efficiency criteria: modified Nash-Sutcliffe criterion MNS (Chiew and McMahon, 1994), mean absolute error MAE (Ye et al., 1997), and correlation coefficients $\mathrm{R}^{2}$. The MNS criterion is similar to the NashSutcliffe criterion, but it uses square roots of flows instead of absolute flows. It is therefore more sensitive to low flow events than the classical Nash and Sutcliffe (1970) criterion. The mean absolute error characterizes how close the simulated results are from observations at each time step (Ye et al., 1997). The closer the value of any of the three criteria is to one, the better the simulation.

Agreement between observed and simulated streamflows was reasonable over the entire simulated period $(\mathrm{MNS}=0.66$, $\left.\mathrm{MAE}=0.44, \mathrm{R}^{2}=0.58\right)$, taking into account that only the base flow factor, $r$, was calibrated. Differences in accuracy could be observed from year to year: the model was more precise and gave larger efficiency criteria for the dry years (1997-1999) than the wetter years (1994-1996, 2000-2001). The best agreement $\left(\mathrm{MNS}=0.90, \mathrm{MAE}=0.76, \mathrm{R}^{2}=0.90\right)$ was 
obtained for the dry summer 1997 on which the calibration of the percolation rate $r$ was performed. This was expected since it was assumed, for lack of better data, that the fraction of the watershed contributing to percolation was constant. In reality it is not and because of the many springs in the watershed, it could even be affected by the previous year's rainfall. Therefore, more complex reservoir models requiring more parameters were also considered. However, they did not significantly improved baseflow simulations. It was finally decided to use the simplest model as presented above. Note that the lack of knowledge of the complicated underground flow paths is a limitation for any hydrology model applied to watersheds in the Catskills.

It is also of interest to evaluate the model's performance by comparing the timing and intensities of simulated peak flows with observed data. Unlike watersheds where Hortonian overland flow is the dominant process and where peak flows have a short duration (of a few minutes to a few hours), watershed where runoff is generated by saturation excess exhibit broader flow peaks. These peaks occur when a major portion of the watershed contributes to runoff, during periods when total rainfall amounts exceeds evaporation greatly. Moreover, since precipitation data was available on a daily basis only, observed and simulated peak flows were compared at the same daily time step.

Peak flow timing, intensities and hydrograph recession were usually well simulated. Occasionally peaks were not reproduced in winter (e.g. 25 January 1996, 6 February 1997, 17 January 1998, 15 Feburary 2000 in Figs. 5c-g, respectively), while some peaks were incorrectly simulated during observed low winter flows (e.g. 23 January 1997, 22 March 1999 in Figs. 5d and f, respectively). This discrepancy was attributed to the use of off-site climate data, as described below.

Agreement between observed and simulated flows was better during summer (MNS $=0.66, \mathrm{MAE}=0.47, \mathrm{R}^{2}=0.63$ ) than during winter $\left(\mathrm{MNS}=0.51, \mathrm{MAE}=0.33, \mathrm{R}^{2}=0.54\right)$. Here again, peak timing and intensities were generally well predicted, with a slight underestimation of peakflows. A significant underestimation of peakflows was observed in August 2000 (Fig. 5g), when precipitation occurred late in the season, as short-duration, high-intensity summer thunderstorms over dry soils. Low flows were usually underestimated (e.g. August 1998 and July 1999).

Three main sources can explain the occasional poor matches between observed and predicted hydrographs. First, water balance components are not perfectly modeled. Snowmelts are only crudely estimated by the temperature-index method currently implemented. More realistic snowmelt routines involve calculation of a radiation balance, even simplified (Walteret al., 2005), but required data were not readily available. Soil freezing and interactions between rainfall and snow cover should also be taken into account. Moreover, infiltration-excess overland flow during summer months is modeled on impervious areas only and not on other soils, which for high rainfall intensity summer storms will likely cause the underestimation of peakflows such as were observed in August 2000. Also, SMDR takes into account perched water tables only, and regional groundwater only indirectly. The latter is a direct consequence of the lack of information about the subsoil structure and the location of subsurface flow paths.

An additional source of errors comes from non-optimal parameter calibration. For example, an overestimation of the soil drainage properties would lead to too rapid a depletion of the water storage by lateral flows, causing an underestimation of percolation during summer months. This hypothesis can explain the simulation of lower summer flows than were observed.

Finally, weather data were obtained from an offsite station about $20 \mathrm{~km}$ from the site. In the summer, thunderstorms are localized, and precipitation measured at Delhi, NY may not equal precipitation occurring onsite. For example, on 7 August 2000, $18 \mathrm{~mm}$ of rain (as recorded in Delhi) produced only $0.7 \mathrm{~mm}$ of streamflow at the watershed outlet, while three days later, $15 \mathrm{~mm}$ of rain produced $7.3 \mathrm{~mm}$ of streamflows. It is likely that the actual precipitation for the storm that hit Delhi on 7 August 2000 was in fact much less on the study watershed. Model results may improve substantially with the use of on-site climatic data. Similarly, the use of off-site temperature data may have contributed to the imperfect reproduction of snowmelt events.

\section{SMDR model distributed results}

Alone, comparison of observed and simulated hydrographs is not a sufficient check of the distributed accuracy of hydrological models. For example, Refsgaard and Knudsen (1996) observed that after proper calibration, a conceptual lumped model (NAM) and a physically-based distributed model (MIKE-SHE) predicted streamflows equally well. Similarly, Johnson et al. (2003) compared SMDR results with outputs simulated by HSPF, an infiltration-excess based semi-distributed conceptual model. Both models gave equally accurate hydrographs despite their different runoff generation mechanisms (Johnson et al., 2003).

A classical approach to assess the efficiency of a distributed model such as SMDR consists in the quantitative comparison of observed and simulated moisture contents at various locations throughout the watershed. Such a method is intrinsically limited by its local character, as samples are taken at specific locations, on particular dates. Even if this approach provides valuable information about the hydrodynamic characteristics of the soils where the samples are taken, it usually fails to identify variable source areas on a larger scale and to capture their dynamics.

A complementary validation consists in using direct information about the location of springs, ephemeral stream paths and saturated areas, as obtained with GPS and mapping 
(Mehta et al., 2001, 2004), or indirect information about the position of hydrological features in the landscape. For example, diversion ditches and tile drains are usually installed to intercept overland flow and subsurface lateral flows, respectively, thus indicating the regular occurrence of runoff generating areas upslope of these installations. In a related way, certain vegetation types, such as ferns and marsh grasses, grow preferentially in wet areas, and could be used as an indicator of the location of areas prone to generate runoff. Both direct and indirect validation approaches are presented below.

\subsection{Transect sampling}

Soil samples were collected at $10-\mathrm{m}$ intervals along three transects on two occasions (8 June 2001 and 5 December 2001). The transects were chosen to represent various land uses and topography. A forested transect ("F") was located on a steep hillslope, over bedrock-limited soils. Transect ("P") was located on pasture fields, on gently sloping soils overlying a fragipan. Transect ("S") was located on moderately steep shrubland. Sampling locations were identified by GPS for the eastern ("P") and middle ("S") transects, but could not be obtained the forested transect ("F") because of the interference from tree canopy. The location of this latter transect was therefore only approximated from the DOQQ. Transect positions are plotted on the land use map in Fig. 4.

Single cores $\left(48 \mathrm{~cm}^{3}\right)$ were taken from each location at a depth from 2 to $6 \mathrm{~cm}$. Each core was weighted and dried to determine gravimetric moisture content and soil bulk density. The samples were also sieved $(2 \mathrm{~mm})$ to correct the results for rock content. Soil moisture saturation degree was calculated as:

$\Theta=\frac{m_{w}}{V_{c}-m_{s} / \rho_{s}}$

where $m_{w}$ and $m_{s}$ are the measured mass of water and dry soil in the sample, $V_{c}$ the core volume and $\rho_{s}$ the particle density, after correction by the organic matter content. Relative errors on the core volumes were estimated at 10 to $15 \%$. Other uncertainties about weight measurements and particle density led eventually to an approximate relative error on saturation degree about 20 to $30 \%$.

Additional soil moisture information was available from a previous sampling campaign (6 May, 30 June, 28 October 1994 and 18 January 1995) on a fourth transect (noted "P2"), located on moderately steep pastures (Frankenberger et al., 1999). For these data, saturation degrees were calculated as the ratio of volumetric water content values and an average porosity of $0.45 \mathrm{~cm}^{3} . \mathrm{cm}^{-3}$, as reported by Frankenberger et al. (1999). Absolute errors on volumetric contents and porosity were estimated for this transect as about 0.07 $\mathrm{cm}^{3} . \mathrm{cm}^{-3}$ and $0.04 \mathrm{~cm}^{3} . \mathrm{cm}^{-3}$, respectively (Frankenberger et al., 1999), giving an absolute error about $0.11 \mathrm{~cm}^{3} . \mathrm{cm}^{-3}$ on saturation degrees.
Table 4. Correlation coefficient $\left(\mathrm{R}^{2}\right)$, relative standard error (RRSE) and Normalized Average Square Residual (NASR) of the comparison between observed and simulated saturation degree on each transect.

\begin{tabular}{lccc}
\hline & NASR $^{\mathrm{a}}(\%)$ & $\mathrm{R}^{2}$ & RRSE $^{\mathrm{b}}(\%)$ \\
\hline Transect S (shrubs) & & & \\
Without calibration & 26.5 & 0.34 & 12.6 \\
8 June 2001 & 20.5 & 0.56 & 7.3 \\
5 December 2001 & 29.3 & 0.83 & 3.4 \\
After calibration & 10.3 & 0.77 & 8.6 \\
8 June 2001 & 15.6 & 0.86 & 8.8 \\
5 December 2001 & 6.9 & 0.75 & 5.6 \\
\hline Transect P (pasture) & 20.0 & 0.05 & 15.3 \\
8 June 2001 & 17.7 & 0.43 & 3.7 \\
5 December 2001 & 20.6 & 0.04 & 13.0 \\
\hline Transect F (forest) & 20.5 & 0.42 & 16.7 \\
8 June 2001 & 24.2 & 0.78 & 10.5 \\
5 December 2001 & 9.4 & 0.93 & 3.4 \\
\hline Transect P2 (pasture) & 12.5 & 0.51 & 9.3 \\
6 May 1994 & 13.1 & 0.72 & 8.5 \\
30 June 1994 & 12.7 & 0.46 & 6.4 \\
28 October 1994 & 3.4 & 0.41 & 1.8 \\
15 January 1995 & 14.5 & 0.84 & 3.9 \\
\hline
\end{tabular}

a NASR: Normalized Average Square Residual. ${ }^{\mathrm{b}}$ RRSE: Regression Relative Standard Error.

Comparisons of observed and simulated saturation degrees are presented for each transect on Figs. 6a-d. A 3-point moving average was calculated for both the simulated and observed values to smooth outliers (lines). On each plot, the estimated error margin is presented as the grey area. A vertical dash line represents the approximate transition point from one soil type to another. Correlation coefficients $\left(\mathrm{R}^{2}\right)$ and relative standard errors (RRSE) of the linear regression between observed and simulated 3-point moving averages are reported for each of the four transects in Table 4, along with the average square residual NASR (normalized by the simulated average). Noting $\Theta_{o b}, \Theta_{s m}, \Theta_{f t}$ the observed, simulated and regression-fitted saturation degrees, respectively, the relative standard error RRSE and the average square residual are defined as

$$
\begin{gathered}
\text { RRSE }=\left(\overline{\Theta_{s m}}\right)^{-1} \sqrt{\frac{1}{n-2} \sum_{i=1}^{n}\left(\Theta_{s m, i}-\Theta_{f t, i}\right)^{2}} \\
\text { NASR }=\left(\overline{\Theta_{s m}}\right)^{-1} \sqrt{\frac{1}{n} \sum_{i=1}^{n}\left(\Theta_{s m, i}-\Theta_{o b s, i}\right)^{2}}
\end{gathered}
$$

For the shrubland transect "S" on 8 June 2001 (Fig. 6a), simulated degrees of saturation matched observations on the 
Shrubland transect 'S'

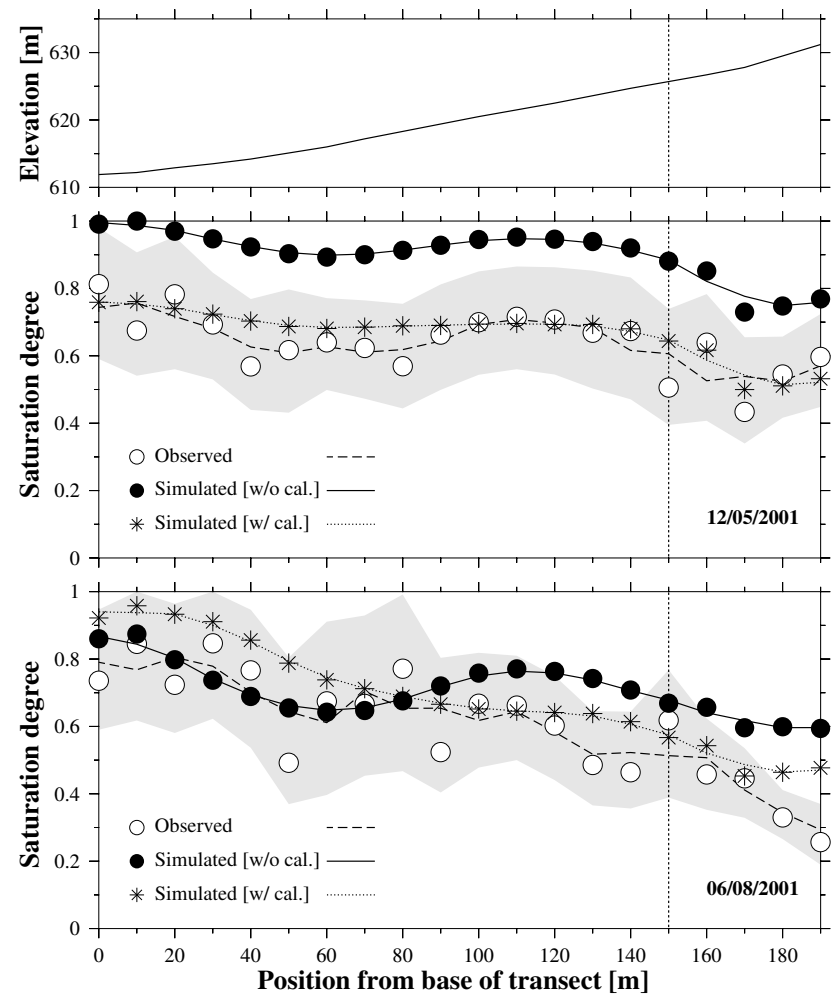

Pasture transect ' $\mathbf{P}$ '

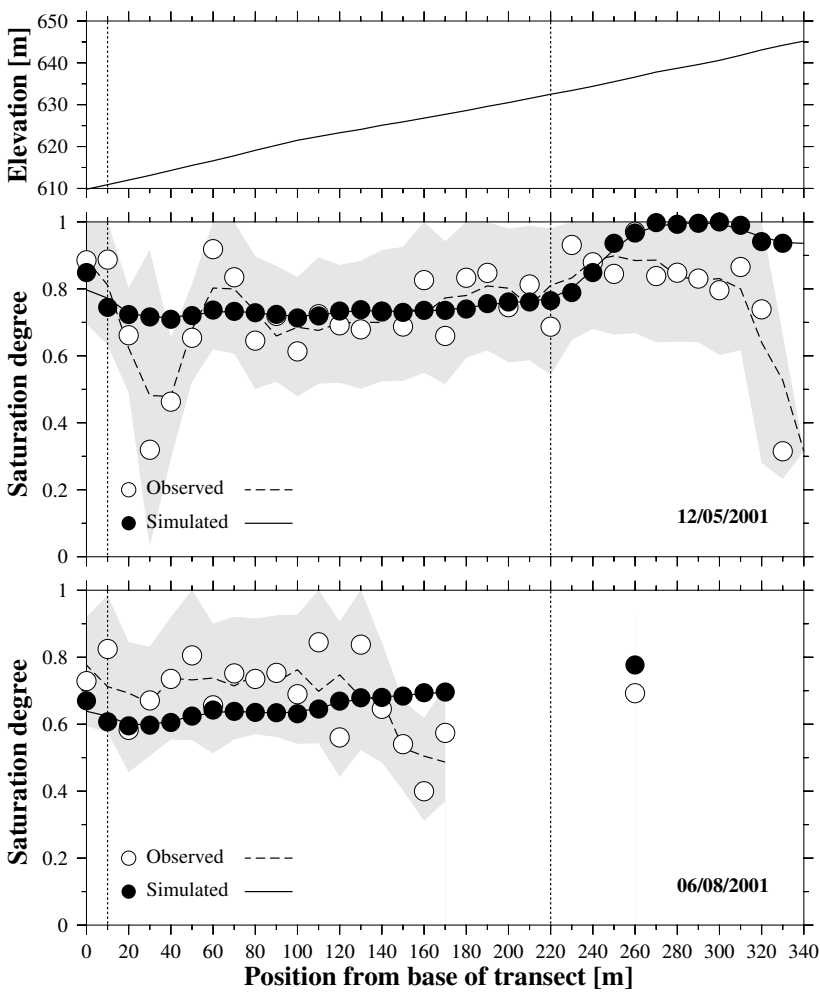

Fig. 6. Comparison between observed (open symbol, dashed line) and simulated (solid symbol and lines) saturation degrees along four transects, (a) shrubland transect "S", (b) pasture transect "P". Simulated results after calibration presented on transect (a) (star symbol, dotted line).

bottom half of the transect, but overpredicted them on the top half, while showing the same generic trend $\left(\mathrm{R}^{2}=0.56\right.$, NASR=0.21). On 5 December 2001, simulations systematically overestimated observations by about $33 \%$, but still had a similar trend $\left(\mathrm{R}^{2}=0.83\right.$, NASR $\left.=0.29\right)$. These results indicate that the drainage characteristics of the upper portion of the transect were underestimated. Indeed, when the average porosity value measured on the site is used instead of the SSURGO estimates, and when the hydraulic conductivities at saturation are set to the higher limits reported in the SSURGO database, simulated results have a much better fit to observations, as illustrated Fig. 6a $\left(\mathrm{R}^{2}=0.86\right.$, NASR $=0.09$ for 8 June and $R^{2}=0.75$, NASR $=0.06$ for 5 December). For the pasture transect "P", simulated saturation degrees are in close agreement with observed moisture contents on both dates $\left(\mathrm{R}^{2}=0.43\right.$, NASR $=0.17$ for 8 June and $\mathrm{R}^{2}=0.04$, NASR $=0.21$ for 5 December). Observed data points at 30 and $330 \mathrm{~m}$ on 5 December had suspiciously low measured water content, and are likely outliers. These outliers explain the low values of the $R^{2}$. Corresponding error margins were adapted in consequence. Results were also satisfactory for transect "F" (forest) on both dates in Fig. 6c, correctly reproducing the observed greater saturation at the flatter base of the slope than on the steeper upper section $\left(R^{2}=0.78, N A S R=0.24\right.$ for 8 June and $R^{2}=0.93$, NASR $=0.09$ for 5 December). On 8 June 2001, however, the model did not reproduce as sharp a decrease in saturation degree with slope change as was observed at $70 \mathrm{~m}$ from the bottom of the slope.

Finally, observed saturation degrees (Fig. 6d) were also well reproduced for the fourth transect "P2", with however a slight systematic overestimation of saturation degrees on 18 January 1995, and overestimation on the bottom part of the transect on 6 June $1994\left(\mathrm{R}^{2}=0.51\right.$ and NASR $=0.13$ on the four dates).

Overall, the trend of moisture distribution along selected transects was reasonably well reproduced, although simulated saturation degrees did not match observations at some locations at some dates. Discrepancies between observed and simulated results originated partly from experimental errors in the determination of saturation degrees and partly from the potential lack of representativity of the samples. Thus, some errors were introduced by using only relatively shallow samples for comparison with moisture contact simulated over the 

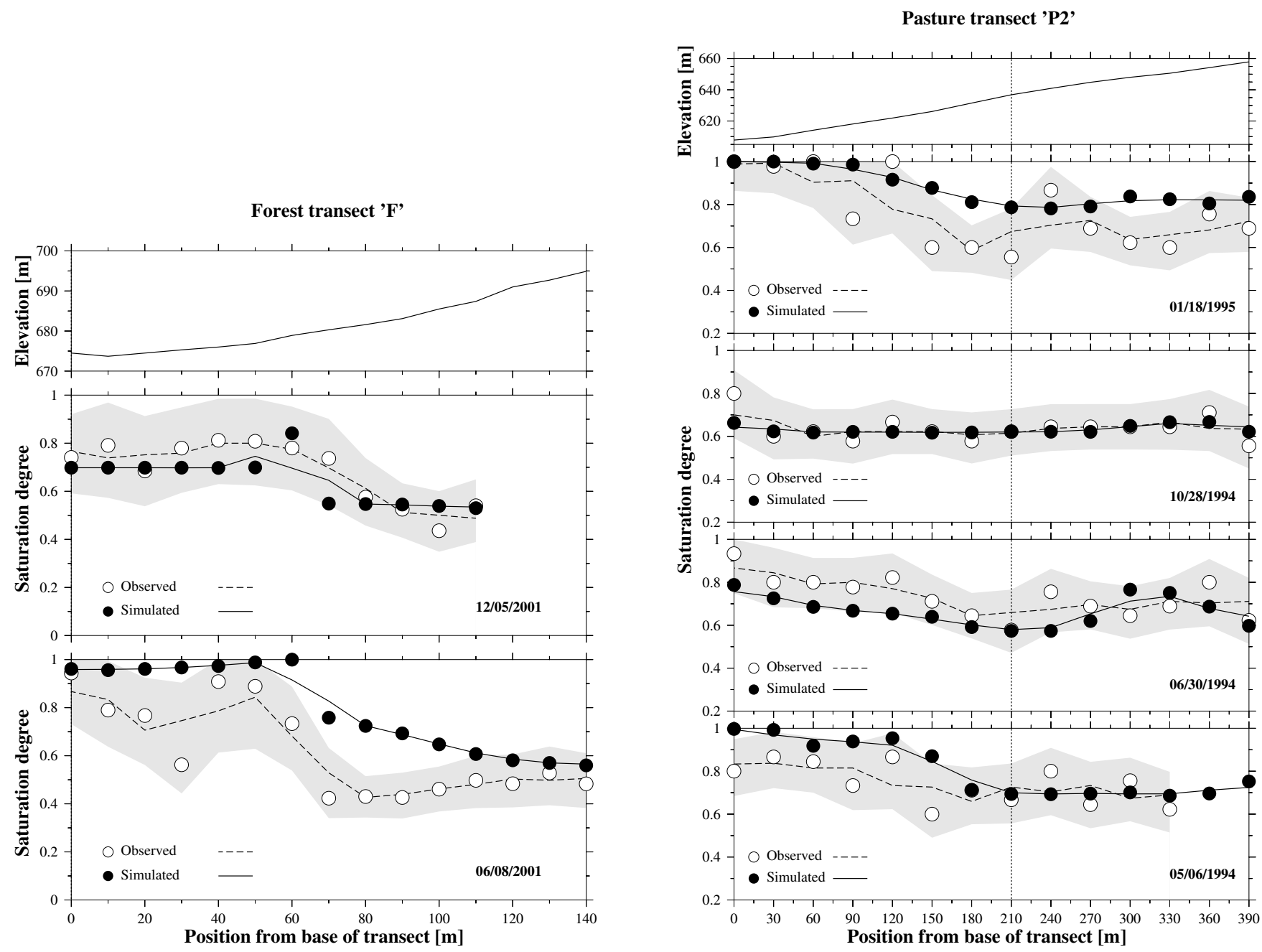

Fig. 6. Continued. (c) forest transect "F", (d) transect "J". Symbols: Saturation degrees. Lines: 3-points moving average. Grey stripe: experimental error. Vertical dash line: soil transition.

entire depth of the soil column. However, it should be noted that the stone content of these soils is high, making it difficult to take samples at deeper depth. Moreover, the spring samples were taken during a relatively dry period, and the winter samples during a relatively wet period. Therefore, a large gradient in moisture content with depth was not expected. Nevertheless, the moisture content for the top soil could systematically underpredict the average moisture content over the whole soil column.

At last, errors originate also from the soil properties input dataset used in the simulation. The SSURGO database describes characteristic soils, and by its statistical nature cannot account for local variability. Therefore, the parameters derived from SSURGO are only approximate. A better match of simulations and observations could be achieved by calibrating the soil hydrodynamic characteristics on a soil by soil, or even field by field, basis, as illustrated by the better fit obtained on transect "S" after calibration. However, such a punctual adjustment of parameters would defy the original purpose of SMDR, i.e. a fully distributed model that requires little calibration, and would lead naturally to the overparametrization pitfall pointed out by Beven (1996), without gaining much accuracy in the overall location of wet areas.

\subsection{Mapping of saturated areas}

Eight 30-cm CIR DOQQs covering the watershed were taken on April 2001 (NYSDoS, 2000). These orthophotographs provided basemaps for the digitization of natural hydrological features (streambeds, pond, main springs) and drainage features (diversion ditches, tile drains). Additional information, including farmer interview and field observations, was used to map the frequently saturated areas (also called wet spots). These wet spots are circled with a yellow line in 


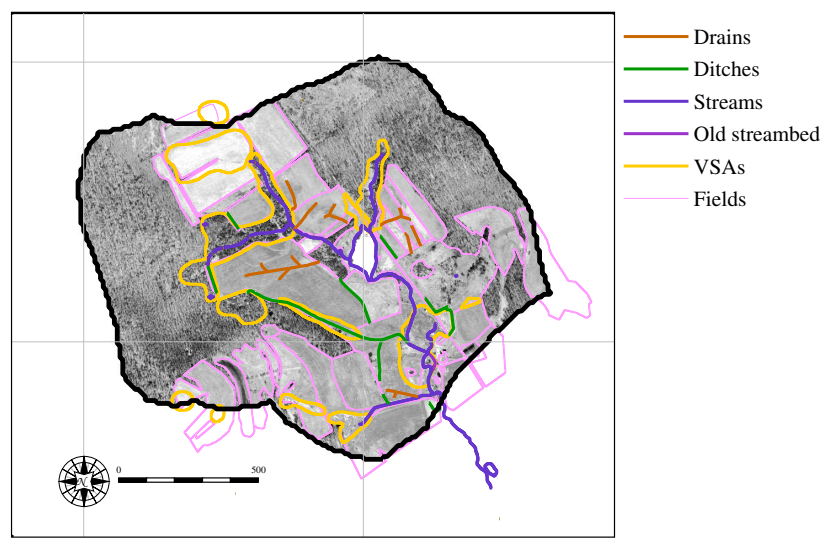

Fig. 7. Position of natural (streams: blue, old streambed: purple) and artificial (drains: brown, ditches: green) drainage features, and estimated positions of empirical frequently saturated hydrologic source areas ("wet spots" or VSAs: yellow), as digitized from a 1-m resolution DOQQ.

Fig. 7 (dark grey in Fig. 8). Although the determination of the location and extent of these wet spots is subjective, the structures installed to drain these wet areas are not: they include drainage tile lines (brown orange in Fig. 7 and green in Fig. 8) and open drainage ditches (green in both Figs. 7 and 8). The stream network starting at the saturated areas is also shown in Fig. 7 in blue. The original position of the stream, before its diversion near the barns in the early nineties, is reported in purple. In addition, field boundaries (in pink) are also drawn to facilitate comparison and localization of features.

Simulated daily runoff volumes for the entire period were summed and averaged over the summer (May-October) and winter (November-April) periods, to create the maps in Fig. 8. Note that SMDR calculates runoff as the depth of water in excess of saturation and tile outflow is therefore included in the simulated runoff. Figure 8a shows that in the summer, most runoff is generated on impervious areas by infiltration excess. Only a small fraction of the pervious areas of the watershed produces runoff in summertime. However, the stream network can still be distinguished. As surface runoff is not explicitly routed in SMDR, stream cells are not connected. Since the stream flowing from the pond had water all summer, the agreement is satisfactory. During winter the comparison between expected (Fig. 7) and simulated (Fig. 8b) is in general good since all the drainage structures and most of the identified wet spots are within the area generating at least $3 \mathrm{~cm} /$ month in average (blue color). This blue area roughly overlays the fragipan-restricted lower terrains. The steeper northeastern slopes produce more runoff than the gentler western slopes. Variable source areas are concentrated in converging areas, slope breaks, and transition between bedrock- and fragipan-restricted soils. In addition, the streams and the surrounding wet areas generate the higher runoff amounts (shown in black), as expected. A closer in-
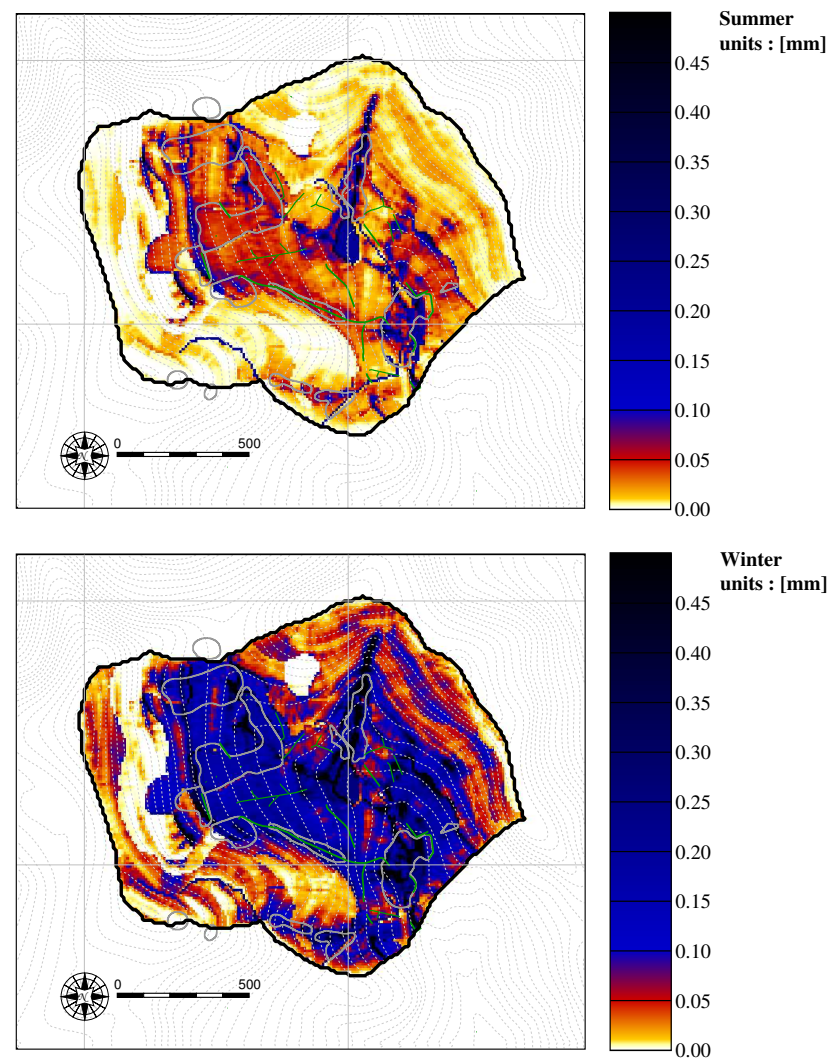

Fig. 8. Seasonal runoff generation on the study watershed, boundaries of estimated source areas (grey) and position of drains and ditches (green). (a) Summer (May-October); (b) Winter (November-April). Runoff volumes expressed in (mm) (1 $\mathrm{mm} \cong 1637.7 \mathrm{~m}^{3}$ ).

spection shows that certain features are not predicted well, such as the wet spots on the south east watershed boundary. These wet spots are likely associated with subsurface features not simulated in the model. Also, part of the stream in the northwest portion of the watershed fades into the background.

Western (2005) asks the fundamental question if these kinds of prediction tools are sufficiently accurate to be used as a management tool. He defines accurate as "predicting high spatial runoff generation zones such that false negatives and false positives both constitute less than $10 \%$ of the total high runoff area". On a pixel-to-pixel basis, SMDR would not meet this criterion. However, management is based on a field-by-field basis and not on a pixel basis. Since the general locations are predicted correctly on a field basis, the model performs well. Moreover if time is included as a factor (i.e., small runoff-producing areas in summer versus to larger areas in winter), the predictions of SMDR might actually meet the $10 \%$ criterion. This is not to say that improvements are not needed, but they may be difficult to achieve since they would require better spatial input on the characteristics of the subsoil. 


\section{Conclusions}

Results of the hydrological model were good considering the minimal calibration. Hydrographs were generally properly simulated, both in terms of timing and intensity of peaks, although summer baseflows were often underestimated, and some winter peakflows were improperly reproduced. Agreement between observed and simulated saturation degrees along four transects at different dates were usually correct. Visual comparison of seasonal cumulative runoff maps and digitized hydrological features was also very encouraging. Improvements should focus on a better representation of snowmelt and soil freezing during winter periods, baseflow generation mechanisms during summer periods, and simple estimation rules for some of the hydrodynamic properties (macroporous drainage limit and horizontal hydraulic conductivity). However, given the limited information about spatially distributed nature of soils, the question remains how the suggested improvements can best be implemented to obtain more accurate simulated distributed moisture contents.

Acknowledgements. The United States Department of Agriculture, through the National Research Initiative funding, and Department of Interior provided primary funding for this study. The grant of the Department of Interior was administered by the New York State Water Resources Institute. Additional funding was provided by the United States Department of Environmental Protection under the Safe Drinking Water Act, administered by the Watershed Agricultural Council (WAC). The data for validation was obtained from P. Bishop of the New York State Department of Environmental Conservation (NYSDEC). M. R. Rafferty, J. L. Lojpersberger of NYSDEC and S. Pacenka of WRI are acknowledged for the collecting and/or modification of this data. In addition, we would like to thank the members of the Town Brook Research Group, Watershed Agricultural Program Planners and Landowners for their invaluable discussions and insights regarding watershed processes in the Catskill Mountains. Specifically we would like to thank the collaborating farm family for their willingness to participate in the research effort and their patience in dealing with us.

Edited by: N. Romano

\section{References}

Abbott, M. B., Bathurst, J. C., Cunge, J. A., O’Connell, P. E., and Rasmussen, J.: An introduction to the European hydrological system - Système Hydrologique Européen, "SHE", 1. history and philosophy of a physically based, distributed modeling system, J. Hydrol., 87, 45-59, 1986a.

Abbott, M. B., Bathurst, J. C., Cunge, J. A., O'Connell, P. E., and Rasmussen, J.: An introduction to the European hydrological system - Système Hydrologique Européen, "SHE", 2. structure of a physically based, distributed modeling system, J. Hydrol., 87, 61-77, 1986b.

Allen, R. G., Pereira, L. S., Raes, D., and Smith, M.: Crop evapotranspiration - Guidelines for computing crop water requirements - FAO Irrigation and drainage paper 56, FAO - Food and Agriculture Organization of the United Nations, Rome, IT, http://www.fao.org/docrep/X0490E/X0490E00.htm, 1998.

Arnold, J. G., Allen, P. M., and Bernhardt, G.: A comprehensive surface-groundwater flow model, J. Hydrol., 142, 47-69, 1993.

Arnold, J. G., Williams, J. R., Srinivasan, R., King, K. W., and Griggs, R. H.: SWAT, Soil and Water Assessment Tool, USDA, Agriculture Research Service, Temple, TX 76502, 1994.

Beven, K. J.: A discussion of distributed hydrological modelling, in: Distributed Hydrological Modelling, edited by: Abbott, M. B. and Refsgaard, J. C., Kluwer, Dordrecht, NL, 255-277, 1996.

Beven, K. J. (Ed.): Distributed modeling in hydrology: Applications of the TOPMODEL Concept, Adv. Hydrol. Proc. Wiley, Chichester, 1997.

Beven, K. J. and Kirkby, M. J.: A physically based, variable contributing area model of basin hydrology, Hydrol. Sci. Bull., 24, 43-69, 1979.

Bicknell, B. R., Imhoff, J. C., Kittle Jr, J. L., Donigian, A. S., and Johanson, R. C.: Hydrological Simulation Program-Fortran: User's manual for version 11, US Environmental Protection Agency, National Exposure Research Laboratory, Athens, GA, 1997.

Bishop, P. L., Hively, W. D., Stedinger, J. R., Bloomfield, J. A., Rafferty, M. R., and Lojpersberger, J. L.: Multivariate analysis of paired watershed data to evaluate agricultural BMP effects on stream water phosphorus, J. Env. Qual., 34, 1087-1101, 2005.

Bishop, P. L., Rafferty, M., and Lojpersberger, J.: Event based water quality monitoring to determine effectiveness of agricultural BMPs, Proceedings of the American Water Resources Association, International Congress on Watershed Management for Water Supply Systems, 29 June-2 July, 2003.

Boll, J., Brooks, E. S., Campbell, C. R., Stockle, C. O., Young, S. K., Hammel, J. E., and McDaniel, P. A.: Progress toward development of a GIS based water quality management tool for small rural watersheds: modification and application of a distributed model, ASAE Annual International Meeting, Orlando, FL., ASAE paper 982230, 1998.

Bresler, E., Russo, D., and Miller, R. D.: Rapid estimate of unsaturated hydraulic conductivity function, Soil Sci. Soc. Amer. J., 42, 170-177, 1978.

Brooks, R. H., and Corey, A. T.: Hydraulic properties of porous media, Colorado State Univ., Colorado, 1964.

Chiew, F. H. S. and McMahon, T. A.: Application of the daily rainfall-runoff model MODHYDROLOG to 28 Australian catchments, J. Hydrol., 153, 383-416, 1994.

DiLuzio, M. D. and Arnold, J. G.: Formulation of a hybrid calibration approach for a physically based distributed model with NEXRAD data input, J. Hydrol., 298, 136-154, 2004.

Donigian, A. S., Bicknell, B. R., and Imhoff, J. C.: Hydrological Simulation Program - Fortran (HSPF), Water Resour. Pubs., Colorado, 1995.

Dunne, T. and Black, R.: Partial area contributing to storm run off in a small New-England watershed, Water Resour. Res., 6, 12961311, 1970.

Dunne, T., Moore, T. R., and Taylor, C. H.: Recognition and prediction of runoff-producing zones in humid regions, Hydrol. Sci. Bull., 20, 305-327, 1975.

ESRI: ArcView GIS 3.3, India, 2002.

Frankenberger, J. R., Brooks, E. S., Walter, M. T., Walter, M. F., and Steenhuis, T. S.: A GIS-based variable source area hydrology 
model, Hydrol. Processes, 13, 805-822, 1999.

Gburek, W. J., Sharpley, A. N., and Pionke, H.: Identification of critical source areas for phosphorus export from agricultural catchments, in: Advances in Hillslope Processes, edited by: Anderson, M. and Brookes, S., John Wiley \& Sons, Chichester, UK, 263-282, 1996.

Goudriaan, J. and van Laar, H.H.: Modelling Potential Crop Growth Processes, Textbook with Exercises, Kluwer Academic Publishers, 1994.

Haith, D. A., Mandel, R., and Wu, R. S.: Generalized watershed loading functions version 2.0: User's manual, Tech. rep., Dept. of Agricultural and Biological Engineering, Cornell University, New York, 1992.

Haith, D. A. and Shoemaker, L. L.: Generalized watershed loading functions for stream flow nutrients, Water Resour. Bull., 23, 471478, 1987.

Hargreaves, G. H. and Samani, Z. A.: Reference crop evapotranspiration from temperature, Appl. Eng. Agric., 1, 96-99, 1985.

Hewlett, J. D. and Hibbert, A. R.: Factors affecting the response of small watersheds to precipitation in humid regions, in: Forest hydrology, edited by: Sopper W. E. and Lull, H. W., Pergamon Press, Oxford, UK, 275-290, 1967.

Hewlett, J.D. and Nutter, W.L.: The varying source area of streamflow from upland basins, Proc. of the Symp. on Interdisciplinarity Aspects of Watershed Mgmt. 08/06/1970, ASCE, Montana, 1970.

Hively, W. D.: Phosphorus loading from a monitored dairy farm landscape, Ph.D. dissertation, Cornell University, Ithaca, NY, 2004.

Horton, R. E.: The role of infiltration in the hydrological cycle, Transactions of the American Geophysical Union, 14, 446-460, 1933.

Horton, R. E.: An approach toward a physical interpretation of infiltration capacity, Soil Sci. Soc. Amer. Proc., 4, 399-418, 1933.

Jensen, M. E., Burman, R. D., and Allen, R. G. (Eds.): Evapotranspiration and Irrigation Water Requirements, Vol. 70 of ASCE Manuals and Reports on Engineering Practice, American Society of Civil Engineers, New York, 1990.

Johnson, M. S., Coon, W. F., Mehta, V. K., Steenhuis, T. S., Brooks, E. S., and Boll, J.: Application of two hydrologic models with different runoff mechanisms to a hillslope dominated watershed in the Northeastern US: a comparison of HSPF and SMR, J. Hydrol., 284, 57-76, 2003.

Kuo, W.-L., Steenhuis, T. S., McCulloch, C. E., Mohler, C. L., Weinstein, D. A., DeGloria, S. D., and Swaney, D. P.: Effect of grid size on runoff and soil moisture for a variable-source-area hydrology model, Water Resour. Res., 35, 3419-3428, 1999.

Mehta, V. K., Johnson, M. S., Gérard-Marchant, P. G. F., Walter, M. T., and Steenhuis, T. S.: Testing a variable source GISbased hydrology model for watersheds in the northeastern US, the Soil Moisture Routing model, EOS Trans. AGU, 82, Fall Meet. Suppl., Abstract H22I-05, 2001.

Mehta, V. K, Walter, M. T., Brooks, E. S., Steenhuis, T. S., Walter, M. F., Johnson, M. S., Boll, J., and Thongs, D.: Application of smr to modeling watersheds in the Catskills mountains, Env. Model. Assess., 9, 77-89, 2004.

Nash, J. E. and Sutcliffe, J. V.; River flow forecasting through conceptual models, part I - a discussion of principles, J. Hydrol., 10, 238-250, 1970.
NCDC: Climatalogical data annual summary - New York, National Climate Data Center (NCDC), North Carolina, 2000.

Neitsch, S. L., Arnold, J. G., Kiniry, J. R., William, J. R., and King, K. W.: SWAT- Soil and Water Assessment Tool, 2000 - Theoretical documentation, Texas, 2002.

Neteler, M. and Mitasova, H.: Open Source GIS: A GRASS GIS Approach, Kluwer Academic Publishers, Massachusetts, 2002.

NLCD: New York Land Cover Data Set, http://landcover.usgs.gov/ nlcd/show_data.asp?code $=$ NY\&state $=$ New_York, US Geological Survey (USGS), South Dakota, 1997.

NYSDoS: Digitally Enhanced Ortho Imagery Online Link http: //www.nysgis.state.ny.us/gateway/mg/napphtmls/f7.htm, Metadata: http://www.nysgis.state.ny.us/gis3/data/dos.doqq_orthos. html, NYS Department of State Division of Coastal Resources, GIS Unit, New York State, 2000.

Priestley, C. H. B. and Taylor, R. J.: On the assessment of surface heat fluxes and evaporation using large-scale parameters, Mon. Wea. Rev., 100, 81-92, 1972.

Rawls, W. and Brakensiek, D.: Prediction of soil water properties for hydrologic modeling, Watershed Management in the Eighties, ASCE, 293-299, 1985.

Refsgaard, J. C. and Knudsen, J.: Operational validation and intercomparison of different types of hydrological models, Water Resour. Res., 32, 2189-2202, 1996.

Refsgaard, J. C. and Storm, B.: Computer Models of Watershed Hydrology, edited by: She, M. and Singh, V., Water Resource Publications, Colorado, 1995.

Saulnier, G.-M., Beven, K. J., and Obled, Ch.: Including spatially variable soil depths in TOPMODEL, J. Hydrol., 202, 158-172, 1998.

Schneiderman, E. M., Pierson, D. C., Lounsbury, D. G., and Zion, M. S.: Modeling the hydrochemistry of the Cannonsville watershed with Generalized Watershed Loading Functions (GWLF), J. Amer. Water Resour. Assoc., 38, 1323-1347, 2002.

Soil and Water Laboratory: SMDR, the Soil Moisture Distribution and Routing model version 2.0 - Documentation, Dept. of Biological and Environmental Engineering, Cornell University, Ithaca, NY, 2003.

Soren, J.: The groundwater resources of Delaware County, New York, Tech. Rep. Water Res. Comm. Bull. GW-50., USGS, New York, 1963.

Srinivasan, M. S., Hamlett, J. M., Day, R. L., Sams, J. I., and Petersen, G. W.: Hydrologic modeling in two subwatersheds of Lake Wallenpaupack, Pennsylvania, J. Amer. Water Resour. Assoc., 34, 963-978, 1998.

Srinivasan, M. S., Gérard-Marchant, P., Veith, T. L., Gburek, W. J., and Steenhuis, T. S.: Watershed-scale modeling of criticalsource-areas of runoff generation and phosphorus transport, J. Amer. Water Resour. Assoc., 41, 361-375, 2005.

Steenhuis, T. S. and van der Molen, W. M.: The ThornthwaiteMather method procedure as a simple engineering method to predict recharge, J. Hydrol., 84, 221-229, 1986.

Tarboton, D. G.: A new method for the determination of flow directions and upslope areas in grid digitale elevation models, Water Resour. Res., 33, 309-319, 1997.

Thornthwaite, C. W. and Mather, J. R.: The water balance, Tech. Rep. Publ. No. 8, Laboratory of Climatology, New Jersey, 1955.

US Army C.E.R.L.: GRASS 4.1 users' manual, Tech. rep., US Army Construction Engineering Research Laboratory, Illinois, 
1991.

US Army Corps of Engineers: Engineering and design: Runoff from snowmelt, Tech. Rep. EM 1110-2-1406, US Army Corps of Engineers, Govt. Printing Office, District of Columbia, 1960.

US Department of Agriculture, N.R.C.S.: Soil Survey Geographic (SSURGO) database for Delaware County, New York, http:// www.ncgc.nrcs.usda.gov/products/datasets/ssurgo/, 2000.

US Geographical Survey (USGS): New York State Digital Elevation Models (DEM), Davenport quadrangle, Online through Cornell University Geographic Information Resources (CUGIR), Cornell University, New York, http://new-gis.mannlib.cornell.edu/ CUGIR_Data/data1/u40elu.dem.gz, 1998.

Walter, M. T., Brooks, E. S., McCool, D. K., King, L. G., Molnau, M., and Boll, J.: Process-based snowmelt modeling: does it require more input data than temperature-index modeling?, J. Hydrol., 300(1-4), 65-75, 2005.

Walter, M. T., Walter, M. F., Brooks, E. S., Steenhuis, T. S., Boll, J., and Weiler, K. R.: Hydrologically sensitive areas: Variable source area hydrology implications for water quality risk assessment, J. Soil Water Conserv., 3, 277-284, 2000.
Western, A.: Comments on "Distributed hydrological modeling of total dissolved phosphorus transport in an agricultural landscape, part 1: Distributed runoff generation" by Gérard-Marchant et al., 2005”, Hydrol. Earth Syst. Sci. Discuss., 2, 1537-1579 RC S780, available online: http://www.cosis.net/copernicus/EGU/hessd/2/ S780/hessd-2-S780.pdf, 2005.

Wigmosta, M. S., Nijssen, B., Storck, P., and Lettenmaier, D.: The Distributed Hydrology Soil Vegetation Model, Mathematical Models of Small Watershed Hydrology and Applications, Water Resource Publications, Colorado, 2002.

Wigmosta, M. S. and Perkins, W. A.: Simulating the effects of forest roads on watershed hydrology, Land Use and Watersheds: Human Influence on Hydrology and Geomorphology in Urban and Forest Areas, Vol. 2 of Water Science and Application, AGU, 2001.

Wigmosta, M. S., Vail, L., and Lettenmaier, D. P.: A distributed hydrology-vegetation model for complex terrain, Water Resour. Res., 30, 1665-1679, 1994.

Ye, W., Bates, B. C., Viney, N. R., Silvapan, M., and Jakeman, A. J.: Performance of conceptual rainfall-runoff models in low yielding ephemeral catchments, Water Resour. Res., 33, 153-166, 1997.

Zollweg, J. A., Gburek, W. J., and Steenhuis, T. S.: SMoRMod - a gis-integrated rainfall-runoff model, Transactions of the ASAE, 39, 1299-1307, 1996. 